\title{
TOPOPHILIA-EXPOSURE CENTRAL SPACE CONCEPT MODEL
}

\author{
A. M. R. Abante ${ }^{1}$, C. G. R. Abante ${ }^{2}$ \\ ${ }^{1}$ Bicol University, Geodetic Engineering Faculty, Legazpi City, Philippines - anamarie.abante@bicol-u.edu.ph \\ ${ }^{2}$ Bicol University, Research Faculty, Legazpi City, Philippines - cgrabante@bicol-u.edu.ph
}

\section{Commission IV}

KEY WORDS: Topophilia-Exposure, Central Space, Tessellated Bin, Philia-Binning, safety, comfort, origin

\begin{abstract}
:
This study proposes how a hexagon object (rather than a perfect circle) is a better representation of a data bin to visualize weighted spatial information, in analysing location (space center), and sorted local knowledge on 'topophilia-exposure'. This approach which depicts the topographic features sorted in a tessellated bin, correlated with the origin (space center), and geographic knowledge on love of a place (tessellated space), was sought to understand the relationships of 'topo'(topography), 'philia' (love of), and exposure data, sorted in a hexagonal lattice shaped cell or bin as spatial objects, where each hexagon has an area of 100 hectares (tessellated bin mapping unit) at a 1 kilometer continuous interval between centroids (central space of hexagon). The 'topophilia-exposure' central space concept model is designed to look at the 'Phila' factors influencing selected exposed residents situated in spaces at risk. This paper shows the effect of 'Philia' elements in the exposed sample Barangays (villages) in Daraga, and Guinobatan towns, Albay, Philippines. These factors dissuade residents from permanently relocating to safer areas, despite the obvious risks involved with staying. Undesired development and sprawling in vulnerable landscapes and danger zones make reducing disaster risk difficult to accomplish; and relocation is often the required option for some areas. Undoubtedly, the factors of Topophilia complicate even the most logical and scientific options for disaster risk reduction and mitigation. This paper finally concludes that the topophiliaexposure model is a model that reflects the phenomena of disaster risk, Exposure complicated by the "love of land" will prevail, and may increase; surely causing complexities in Disaster Risk Reduction and Management.
\end{abstract}

\section{INTRODUCTION}

\subsection{Framework for Topophilia}

The first settlements, like those prominent in Southeast Asia, were built along or near rivers, and were often influenced by cosmological concepts such as Ken Yu or Feng Sui. In the 1990s, the evolution of modern town planning as a field of study - is traced up to the present day. It deals with network of living and non-lasting things which involves the interaction of the communities and the non-support environment. Impeccable environs in times of imbalances cleanses in a natural phenomenon. However, the term 'cleanses' likely describes a tragedy. Forest and water ecosystems were the primary ecological units before humanity began to harvest and control natural resources. This attraction to these sources of raw materials gradually caused pieces of land to be gradually used for dwelling and production. According to Reed, Filipino houses were also constructed on the riverbanks or over shallow waters. These communities called "barangays" or villages, were settled by separate kinship groups within their respective lands in the 16th Century (Reed, 1967).

This paper introduces Topophilia: the 'love of place (location), as a function of the sense of origin (location), and/or sense of insideness or sense or community. The term topophilia was coined by the geographer Yi-Fu Tuan of the University of Wisconsin and is defined as the affective bond with one's environment.

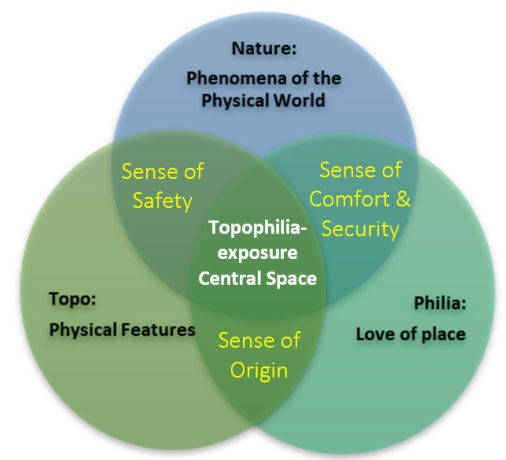

Figure 1. Topophilia-Exposure Central Space Concept Model

The intersections is mathematically expressed as the sets of $\{$ Topophilia-Exposure $\} \sim$ \{Sense of Safety $\cap$ \{Sense of Comfort $\} \cap\{$ Sense of Origin $\}$.

The 'Topo', 'Philia', 'Physical world', 'Sense of Origin', 'Sense of Safety' and 'Sense of Comfort' are elements to assess Topophilia-exposure. The challenging work is modelling the central space brought by taking over the place their lineages' land used to reside in an unfamiliar space may be unsafe but comfortable. In contrast, sometimes a space is uncomfortable because of remote relocation site (space) but safe from disaster risks.

One way of understanding the spaces which exist in the concepts of Nature, Topography, and Topophilia, is to look at them as components of the 'Policy Areas for the Comprehensive Land Use Plan' (DILG, 2008). 'Nature' as used in this paper can be related to the 'Life Support System policy area where the land is left in their open character, as they function best in that state to produce food, provide water, and receive wastes from the 
settlement and production areas. 'Topo'(or Topography) in this study can be linked to the "Space to make a living" policy area, where sites for production are placed to generate resources for consumption. Finally, our understanding of "Topophilia" can be connected to how we see the "Space for Living"as a policy area. These are the settlement sites; the areas where people choose to build their houses upon.

Definitely, these spaces should be seen not as exclusive areas, but as spaces which partly intersect. And in these intersections, we find the motivation to build or not to build.

\subsection{The Study Area}

This paper focuses on the case of two settlement or former settlement areas in the 2nd and 3rd congressional districts of the Province of Albay, Philippines: Budiao in the Town of Daraga, and the Poblacion, in the Town of Guinobatan. Budiao is a barangay (village) situated within a sloping section of the Yawa watershed in the Municipality of Daraga, located at the foot of and dangerously close to - the Mayon Volcano. This village is the constant target of forced evacuations due to volcanic activity. The most recent evacuation was in January 2018 when 420 families were displaced for at least two months (NDRRMC, 2018). It is also the site of an old stone church which was buried during the violent eruption of Mt. Mayon in 1814. This suggests that the village had a considerable population to merit the construction of a stone church, and could even have been inhabited before the Spaniards came in the 1500s. Meanwhile, the Poblacion (central district), of Guinobatan, Albay, has been inhabited since1668, and is considered as the town center. It is part of the Albay Tres Quinali watershed and located beside the San Francisco River (also known as Bicol River), and is about 12 kilometers away from the crater of Mt. Mayon. This area has always been inhabited as early as its foundation as an encomienda in 1574, except for four years (1814-1818) when the town was completely abandoned following the 1814 eruption of the volcano - the same one that buried the church at Budiao. Although settled outside the conventional $8 \mathrm{~km}$ danger zone radius, volcanic material still reached the town: destroying most of its features, and even burying its old cemetery.

Both the settlers of Barangay Budiao [Daraga], and Barangay Poblacion [Guinobatan] experienced considerable disruptions to their domestic and economic lives in the past. The disasters brought by volcanic activity had forced the entire town of Guinobatan to relocate more than $20 \mathrm{kms}$ away; and even until today, the residents of Budiao experience these same disruptions (forced evacuations). Finally, what is similar between these two sites is that despite the obvious dangers brought by their proximity to rivers and the country's most active volcano, their residents choose to resettle the area and remain in the same, without interest to permanently relocate to relatively safer sites.

\subsection{Research problem and objectives}

Pre-hispanic settlements in the Philippines can be described as being organized as a galaxy; scattered and shaped by communal laws and agreements, and influenced by the land-form (water bodies; croplands). Even as the Spaniards formalized the growth of the urban form, the desire to settle in areas accessible to and fro productive and servicing lands have remained. Aside from economic reasons, the trends in land utilization have also been influenced by socio-cultural factors. Settlements in the Philippines tend to follow the paths of major rivers (transportation), strategic coastlines (defense and fisheries), and floodplains (agriculture). This can be seen in how residential areas are built near water-bodies, well within legal and ecological easements. Regardless of the dangers posed by living near or within hazard areas, multiple factors of Topophilia dissuade exposed populations from permanently resettling outside of these danger zones.

The problem which this paper desires to tackle can be asked in the following manner: "How can we understand the dynamics of Topophilia (love of place) in the geophysical space, relative to the risks experienced by the population living in hazardous areas?" This question drives the authors to pursue this study guided by the following objectives: (1) explore the phenomenon on Topophilia among exposed populations/settlements; (2) create a tessellated bin to sort and autocorrelation the elements of topophilia and exposure in ArcGIS platform; and (3) simulate a Topophilia-Exposure model for selected sites.

\section{MAIN BODY}

\subsection{Topophilia Dynamics}

Janelle introduced the argument for central place development in a time-space framework. According to him scholars in geography and related social sciences have recognized that the locational structure of man's economic political and cultural activities is not in a static state (Janelle, 1968).

The topophilia dynamics in this study attempts to initially relate the weighted statistics (regardless of the temporal aspects) of the physical space (regardless of landscape changes overtime) occupied by vulnerable and exposed residents with their love to the land they inherited or presently occupied where repetitive evacuation practices which have become the norm.

'Sense of Safety'. The 'sense of safety' is connected to the natural phenomena and vulnerabilities influenced by the physical characteristics such as the condition of slope, elevation, and soil. Philippine policy on land use and development provides that areas with slopes below eighteen percent (18\%) are generally classified as alienable and disposable land. Further that: a) Twenty-meter (20) strips of land along the edge of the normal high waterline of rivers, and least streams with channel of at least five (5) meters wide; and b) Strips of mangrove or swamplands at least twenty (20) meters wide, along shoreline facing the ocean, lakes, and other bodies of water, and strips of land at least twenty (20) meters wide facing lakes - are non-buildable areas.

The easement policy regardless of the slope of riverbanks and easements for streams, shores of the seas and lakes throughout their entire length within urban and urban use areas are set aside, to be free of any building. These are buffers from inland bodies of water: three (3) meters in urban areas, twenty (20) meters in agricultural areas and forty (40) meters in forest areas along their margins, the easement of public use in the interest of recreation, navigation, floatage, fishing, and salvage. No person shall be allowed to stay in this zone longer than what is necessary for recreation, navigation, floatage, fishing, and salvage or to build structures of any kind [PD705]. Here we understand 'Safety' to be areas where the benefits provided by the natural environment attracts settlements, which build in areas ideally outside of dangerous zoned. Settlements exists outside of areas which are not deemed 'safe' by Philippine law (lands $>18 \%$ slope, buffer zones). 
'Sense of Comfort'. The 'sense comfort' go along with 'Philia or love of place'. The Philippine policy on land or generally states that areas upon which houses will be constructed or any building or structure, or any ancillary or auxiliary facility thereto, shall be sanitary, hygienic or safe. [PD1096] The policy of the state to liberate our human communities from blight, congestion and hazard, and to promote their development and modernization, is also imbedded in policies that regulate urban development [PD1517]. As understood in this paper, the Sense of Comfort is the reason behind the statement "Why I stay here." These areas which are affected by both the safety and amenity of the natural environment (Nature), and the goods and services offered by the urban or built environment. People will tend to live near sites where the cost of accessing goods and services are reduced Getis, 1966). This idea stems from Christaller's Central Place Theory, and while its primary concern is the modeling of urban growth and the shape of the market, it offers us a reference to how settlements gravitate towards the goods and services they enjoy.

'Sense of Origin'. The 'sense of origin' is a composite of the topology and Philia. The 'origin' in this study refers to the location of ancestral or inherited pieces of lands or old settlements that had been utilized for residential purposes, or public spaces that were utilized for dwelling but not allocated for other development. Identities formed as a result of history, or a shared experience also form a part of this. Here, the statement "Who I am here" exists in the experience of the dwellers. Kevin Lynch in his book "Image of the City"states that "Nothing is experienced by itself, but always in relation to its surroundings, the sequences of events leading up to it, the memory of past experiences (Lynch, 1990)." Although his book focuses on the urban setting, the assertion that the experience of a person is tied to the image of a place is a valuable point for this paper to consider.

\subsection{Representing the geophysical space}

Almost every attempt to understand the geophysical space begins with uniformly defining or measuring the physical world in what can be fitted to a mathematical model. Walter Chirstaller (18931969), building on the works of von Thünen and Weber, created a 2-dimensional geometric model of his Central Place Theory. In Christaller's model: the influence of certain urban features (its minimum and maximum range) can be represented as a circle emanating from its location. He then decided that due to the overlaps and non-coverage caused by a circular model, a lattice of hexagons are a better model to represent the geophysical space. This paper makes use of this hexagonal-model, in simulating the implications of Topophilia, and the interactions of its three agents: the physical world, the physical features (settlements and production), and Topophilia (love of place).

Spatial bins for Topography. According to Cappellari \& Copin, "binning" is essential in the case of spectroscopic observations of the stellar kinematics, or the observation of the movement of stars in space. (Cappellari \& Copin, 2003). The authors (Oat, Barczak, \& Shopf, 2008) introduced the efficient spatial-binning as a new technique for sorting data into spatial bins taking points in sorted order into a set of bins. The study of Oksanen on applying binning principles to understand the uncertainty of DEMs (Oksanen, 2013) is similar to what the researchers want to apply to explore 'Topo' (topography) as a local place used to describe the topographic (spatial) features of a local setting (landscape) analyzed within a cell. The centroid of the hexagon shaped cell is used to represent the spatial data collected by method of spatial data binning.
Spatial bins for Topophilia. According to the authors Sui, Elwood, \& Goodchild, geographic knowledge in the context of crowdsourcing deals big data and place inference. (Sui, Elwood, \& Goodchild, 2012) Similarly, Philia (Greek: "[the] love of") is conceptualized as geographic knowledge dealing with the perceptions of local key informants on their locations (residence). The ideas Zamir, Shamai, \& Erez to connect network information theory with the rich areas of linear codes and lattice codes, and have strong potential for practical applications inspired the authors to correlate the 'sense of origin', 'sense of safety' and 'sense of comfort' to describe the 'Philia' through aspatial data binning (Zamir, Shamai, \& Erez, 2002). Finally, The study of Johnson, Burrows, Hartnoll, \& Hawkins on the spatial pattern of limpet grazing drive a mosaic of algal patches on moderately exposed shores in the northeast Atlantic, in which aged algal patches and spatial effects were tested for using spatially referenced data sets exposing rocky shores. (Johnson, Burrows, Hartnoll, Hawkins, 1997).

Although the policy of the Philippines is to mainstream disaster risk reduction and climate change in development processes, exposed settlements and people remain a challenge to the government. The trends in land utilization is seen to be driven by non-spatial factors such as culture, in which it is characterized by the length of occupancy, and sentiments of identity, regardless of safety. The authors tried to explore the spatial patterns of the central space tight correlation of 'Topo' tessellated binned statistical with 'Philia' attributions: topographic features (landscape); natural environment (phenomena of the physical space); 'love of the place'; 'sense of origin'; 'sense of safety'; and 'sense of comfort'.

\subsection{Methodology}

Gold, in his paper described the role of tessesslated models of space within the discipline of geographic information system (GIS) - a specialty coming largely out of geography and land surveying where there was a strong need to represent information about the land surface within a computer system rather than on the original paper. (Gold, 2016)

Figure 2 is a product of Phil-LiDAR 1 Program licensed to Bicol University.

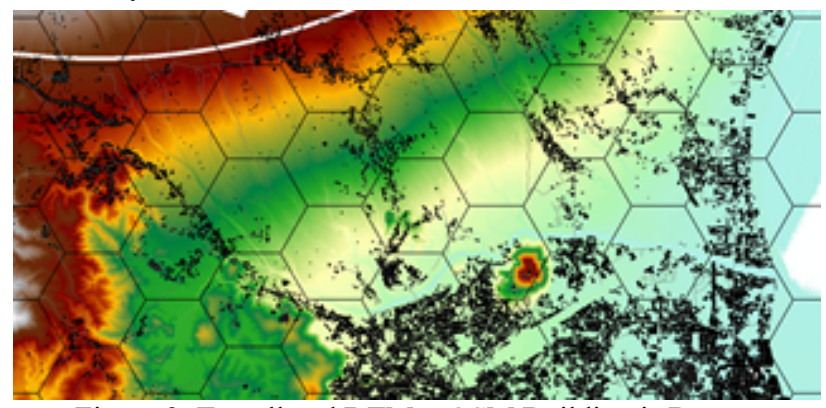

Figure 2. Tessellated DTM + OSM Building is Daraga

The researchers designed the topophilia-exposure prototype by correlating the geographic data (local knowledge) in relation to topographic (landscape) features binned in a tessellation spatial object or cell. A cell is a 100 hectare hexagon-shaped tessellation mapping unit. Cells are categorized into five (5) classes the risk elements, these are: exposure, landscape vulnerability, multiple hazards. These three (3) disaster risk elements are regarded inversely related to resilience, where risk hotspot characterize the 
space with very high numerical value of $z$-score and resilient coldspot characterizes a very low to negligible numerical value of z-score.

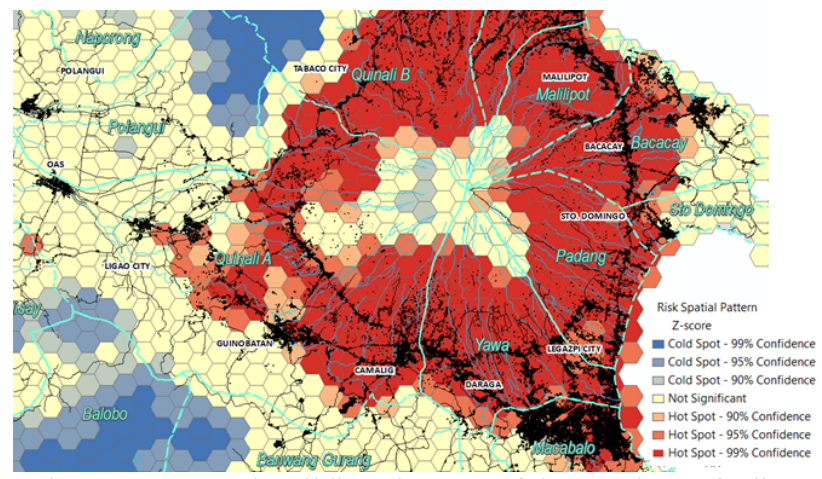

Figure 3. Exposed Buildings in parts of the Province of Albay

Figure 3 shows the tessellated z-scores denoting risk hotspots (unsafe) areas around Mayon Volcano in Albay Philippines overlaid with OpenStreetMap (OSM) Buildings. It discloses the exposed building footprints that coincides or located within the cells may vary from near zero to very high prone to a disaster.

\subsection{The Case of Guinobatan and Budiao as study areas}

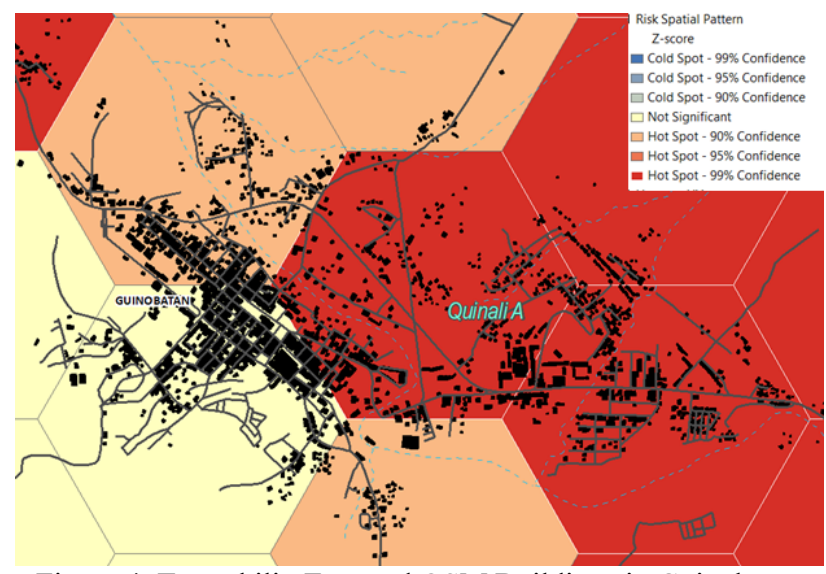

Figure 4. Topophilia-Exposed OSM Buildings in Guinobatan Poblacion

Figure 4 shows the tessellated cell for Guinobatan Poblacion. The eastern portion of the town is $90 \%$ disaster risk hotspot, the right portion adjacent to it is $99 \%$ hotspot, and most of the buildings located in the lower portion have insignificant resulting numerical values (meaning it is difficult to tell if hotspot or safe location). although the sample households near the church ruins are located within safe cell, disaster risk may vary as it is directly adjacent to $90 \%$ to $99 \%$ risky tessellated cells. However, a centennial school building is still standing near the border of $90 \%$ insignificant cell and $90 \%$ unsafe cell.

Figure 5 below shows the tessellated cell for Budiao, Daraga and the surrounding cells are all $99 \%$ unsafe areas.

The Budiao Church Ruins is located in a highly exposed site in which the 1814 eruption of Mayon buried this unsafe area. In 2006, after the Super Typhoon Reming greatly affected with extreme rainfall lahar/debris and dike breaching. (Paguican, Lagmay, Rodolfo, Rodolfo, Tengonciang, Lapus, Obille, 2009)
Based on the technical report entitled "The Mayon 2006 Debris Flow1 The Destructive Path of Typhoon Reming (Int'l Name: Durian)" Buidiao, Daraga is one greatly affected. (Fano, Alpasan, Mitsunaga, Tokunaga, 2007). The Budiao residents including the barangay hall and social services were relocated to the National Housing Authority (NHA) Resettlement Sites in Daraga, Albay. (safer tessellated cell)

Figure is a product of Phil-LiDAR 1 Program licensed to Bicol University overlaid with OSM Buildings, Mayon Permanent

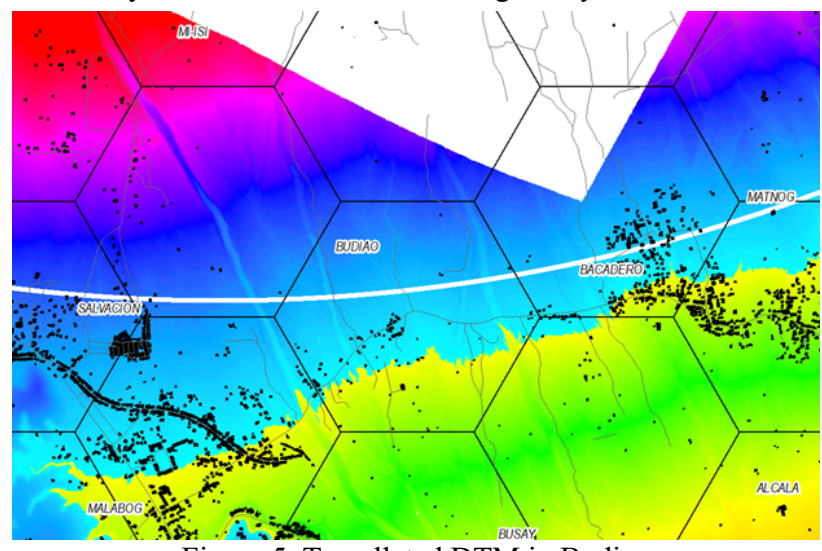

Figure 5. Tessellated DTM in Budiao

The paper of Usamah, \& Haynes investigates the resettlement program for communities impacted by volcanic hazards from Mayon volcano in the Philippines. (Usamah, \& Haynes, 2012) In 2018, the NDRRMC update on the situation per report number 57 re Mayon Volcano Eruption, there are 420 families were evacuated from Barangays "Matnog and "Budiao, Daraga" to evacuation centers in Anislag, Daraga (further south from the volcano) (NDRRMC, 2018).

Sense of Origin and Comfort: Guinobatan. Local histories cited that during Spanish colonial rule Guinobatan saw a gradual expansion of its road networks, connecting it to other towns in the then colonial provinces. This can be seen as an expansion of economic activity, and an improvement in local services. The town, where it presently stands, was serviced by a parish made of stone, a municipal cemetery, and a school for boys. Despite being destroyed in the 1814 eruption of Mayon Volcano, the residents returned to the site only after four years, and began rebuilding the poblacion. It took at least two decades before the town fully recovered from the economic damages. The intention to rebuild the town even as it was ravaged multiple times, can be seen even in the events that took place after the Filipino-American War. The church which had been destroyed by volcano, by arson, and by other causes was restored by as much, due to the funds raised by the locals families, who turned to the brink of financial ruin. Locals have built their cultural identities around the fact that they live in the shadow of a volcano which has continued to negatively affect them until this day.

Despite its appearance, the town is a first-class income municipality. It is serviced by eleven rural and commercial banks, and two ATM-only facilities (BSP 2019), Educational Institutions: one (1) State University; nine (9) secondary schools; and 35 primary schools (DepEd, 2019). It also hosts the basic services required of a municipality such as peacekeeping services, and health service facilities.

There exists a positive motivation for settlers to remain in this site, despite being exposed to natural hazards brought by a 
volcano. Investments in land development, commercial interests, and socio-cultural needs, all contribute to the residents' desire to remain in these locations. In fact, socio-cultural factors such as religious beliefs are increasing Topophilia in areas which should be avoided due to existing hazards. This is referring to the compound-turned-pilgrimage site of a religious Sect known as the "Lola Maria ng Maipon"(Grandmother Maria of Maipon) which attracts and even houses scores of devotees and pilgrims visiting. This site is located in Barangay (village) Maipon, north of the town center, and a disaster risk hotspot.

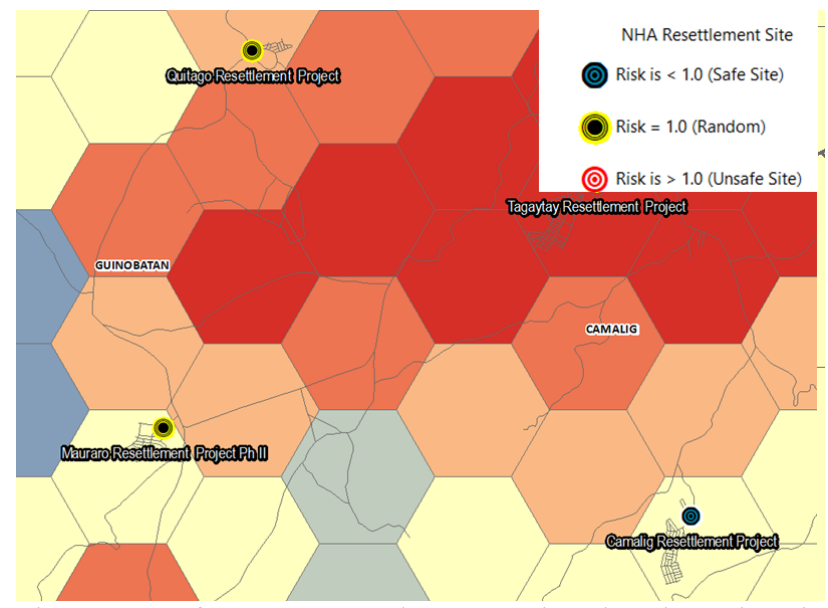

Figure 6. Safe NHA Resettlement and Relocation Sites in Guinobatan

Figure 6 reveals the safe resettlement and housing projects of the NHA in Guinobatan.

Sense of Origin and Comfort: Budiao. The case in Budiao [Daraga, Albay], is different from Guinobatan in many ways, but it does share the common exposure to the dangers brought by the Mayon volcano. For one, Budiao is a lot closer to the crater; Guinobatan is about 12 kilometers away, while residential areas in Budiao are well inside the 8 kilometer danger zone, with some even going as close to 7 kilometers (from the crater). Despite being a rural barangay, Budiao was once an important settlement, which was destroyed in 1814 in what is considered as the most violent eruption of Mayon. We know that Budiao was a center of municipal life because of the of the stone church present at the site. Now a ruin, the church was bigger than the Cagsawa church, and would have been an important feature of life in the former town. Owen (1984) cites the reports that the entire town, which was founded in 1773, was destroyed and that the descendants of its survivors had continued to plea for its restoration as a town, independent of Daraga.

At present, Budiao is a village under the political jurisdiction of the Municipality of Daraga. According to the 2015 census, Budiao only has 288 residents, which represents $0.23 \%$ of the total population of the town (PSA, 2016). Agriculture remains a prevalent source of income and food source among the locals, but what should be noted is the particular interest and value people have for a cultivar of Niyog-niyogan (Ficus pseudopalma Blanco), and Taro (Colocasia esculenta). The leaves of these plants are used as ingredients for local cuisine, and locals believe that cultivars from Budiao are better in quality and taste due to the nutrients of the volcanic soil. While this remains to be a study for other disciplines, we are interested in the value people place in the livelihood and resources provided by their proximity to
'Nature.' Usamah and Haynes (2011) in studying the effects of resettling the residents of Budiao, noted the economic impact of separating people from their farms and sources of livelihood. Houses were built but livelihood was not. In the context of Topophilia, the relocated population had lost their 'sense of comfort'. Residents stay in Budiao because of their attachment to the site. Despite the constant evacuations done (most recent in 2014 and 2018) The community remains in the barangay, with even a restored chapel. The paper further goes to saying that providing a means of living and economic security should be a part of relocation (Usamah, Haynes, 2012).

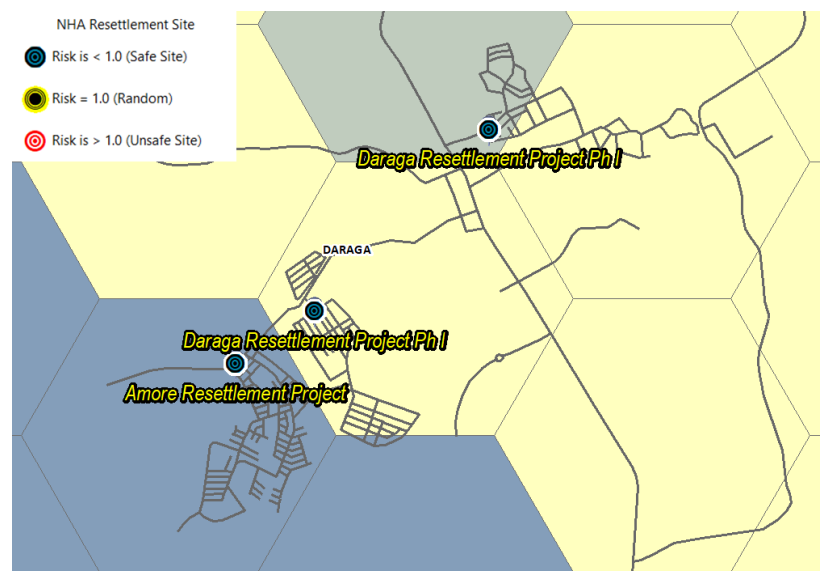

Figure 7. Safe NHA Resettlement and Relocation Sites in Daraga

Figure 7 reveals the safe resettlement and housing projects of the NHA. Despite the safe relocation sites, Figure 4 reveals that some residents resettled back to Budiao.

Topophilia-Exposure data binning practical characterization deals with safety, comfort, and origin sub-elements conceptualized as the overlapping spaces among the three (3) elements of Topophilia-Exposure Central Space as shown in figure 1 .

Figure 6 below was derived from the Disaster Risk Estimates Matrix used to characterize preparedness insufficiency (Abante, December 2018), and risk location distribution matrix (Abante, February 2018). Safety in this study is treated inversely related to disaster risk estimates. The Topophilia-Exposure Spatial Binning Index denotes the following:

$$
\begin{aligned}
& 125=\text { Topophilia-Exposure is unlikely (Insignificant) } \\
& 64>125=\text { Topophilia-Exposure is possible } \\
& 8>64=\text { Topophilia-Exposure is Moderate } \\
& <8>\quad 1=\text { Topophilia-Exposure is somewhat likely } \\
& <1 \quad=\text { Topophilia-Exposure is likely (Significant) }
\end{aligned}
$$

\begin{tabular}{|c|c|c|c|c|c|}
\hline $\begin{array}{l}\text { Topophilia- } \\
\text { Exposure }\end{array}$ & $\begin{array}{l}\text { Strong } \\
\text { sense of } \\
\text { comfort/ } \\
\text { origin }\end{array}$ & $\begin{array}{l}\text { Moderate to } \\
\text { Strong } \\
\text { sense of } \\
\text { comfort/ori } \\
\text { gin }\end{array}$ & $\begin{array}{l}\text { Moderate } \\
\text { sense of } \\
\text { comfort/ori } \\
\text { gin }\end{array}$ & $\begin{array}{l}\text { Least to } \\
\text { Moderate } \\
\text { sense of } \\
\text { comfort/ } \\
\text { Origi }\end{array}$ & $\begin{array}{l}\text { Least sense } \\
\text { of } \\
\text { comfort/ori } \\
\text { gin }\end{array}$ \\
\hline $\begin{array}{ll}\text { Sense of } \\
\text { Safety } & \text { is } \\
\text { unlikely } & \end{array}$ & 125 & 64 & 27 & 8 & 1.0 (Bal.) \\
\hline $\begin{array}{ll}\text { Sense of } \\
\text { Safety } \\
\text { possible }\end{array}$ & 15.63 & 8 & 3.36 & 1.0 (Bal.) & 0.13 \\
\hline
\end{tabular}




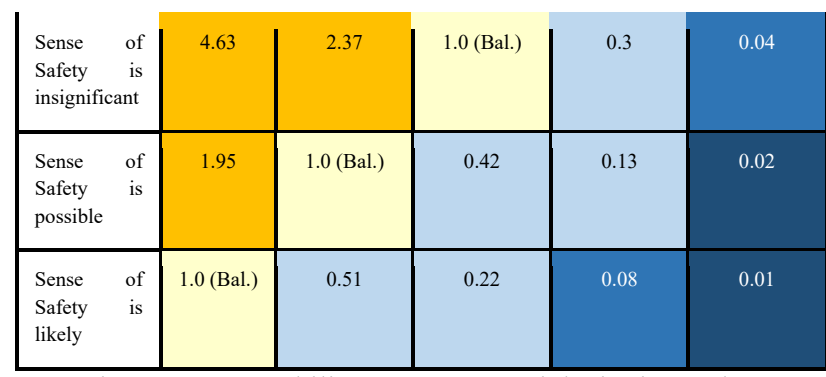

Figure 8 - Topophilia Exposure Spatial Binning Index

This color scheme for Figure 6 is the same for figures 3, 4, 6, and 7. The Red to Dark Red signify a $99 \%$ Risk Hotspot or Unsafe Tessellated Space, but comfort and origin remain variable and difficult to measure; The Light Orange to Red signify a 95\% Risk Hotspot or Unsafe Tessellated Space, but comfort and origin remain variable and difficult to measure; The Light Orange signify a $90 \%$ Risk Hotspot or Unsafe Tessellated Space, but comfort and origin remain variable and difficult to measure; The Light Yellow signify Random value or insignificant tessellated space; The Light Blue signify a $90 \%$ Safe Tessellated Space, but not necessarily a comfortable location (central space that covers 100 hectares of land surface);

Blue signify a 95\% Safe Tessellated Space, but not necessarily a comfortable location; and The Dark Blue signify a 99\% Safe Tessellated Space, but not necessarily a comfortable for some relocated or resettled families.

\begin{tabular}{|c|c|c|c|c|c|}
\hline \multirow[t]{2}{*}{ Study Area } & \multirow{2}{*}{$\begin{array}{l}\begin{array}{l}\text { Sense of } \\
\text { Safety }\end{array} \\
\text { Tessellat } \\
\text { ed Cell }\end{array}$} & \multirow{2}{*}{$\begin{array}{l}\begin{array}{l}\text { Sense of } \\
\text { Comfor } \\
t\end{array} \\
\text { Central } \\
\text { Space }\end{array}$} & \multirow{2}{*}{$\begin{array}{l}\begin{array}{l}\text { Sense } \\
\text { of } \\
\text { Origin }\end{array} \\
\text { Centr } \\
\text { al } \\
\text { Space }\end{array}$} & \multicolumn{2}{|c|}{ Topophilia-Exposure } \\
\hline & & & & $\begin{array}{l}\text { Spatia } \\
\text { I Data } \\
\text { Binnin } \\
\text { g }\end{array}$ & $\begin{array}{l}\text { Significan } \\
\text { ce }\end{array}$ \\
\hline $\begin{array}{l}\text { Daraga } \\
\text { Poblacion } \\
\text { Cells }\end{array}$ & 3 & 4 & 4 & 48 & Moderate \\
\hline Budiao Cell & 1 & 2 & 3 & 6 & $\begin{array}{l}\text { Somewhat } \\
\text { Likely }\end{array}$ \\
\hline $\begin{array}{l}\text { Guinobatan } \\
\text { Poblacion } \\
\text { Cells }\end{array}$ & 4 & 5 & 4 & 80 & $\begin{array}{l}\text { Moderate } \\
\text { Posible } \\
\text { Posible }\end{array}$ \\
\hline $\begin{array}{l}\text { Maipon } \\
\text { Cell }\end{array}$ & 1 & 1 & 3 & 3 & $\begin{array}{l}\text { Somewhat } \\
\text { Likely }\end{array}$ \\
\hline
\end{tabular}

Table1 Topophilia Exposure Findings

Binned Sense of Comfort/Origin Rating:

$1=$ Least sense of comfort/origin

$2=$ Least to Moderate sense of comfort/origin

$3=$ Neutral/Moderate sense of comfort/origin

$4=$ Moderate to Strong sense of comfort/origin

$5=$ Strong sense of comfort/origin

Tessellated Sense of Safety (Inversely related to Disaster Risk):

$1=$ Sense of Safety is likely (Resilient Space)

$2=$ Sense of Safety is somewhat likely (Likely Resilient Space)

$3=$ Neutral (Random)

$4=$ Sense of Safety is possible (High Disaster Risk Space)

$5=$ Sense of Safety is unlikely (Very High Disaster Risk Space)

Table 1 shows the practical implications of Topophilia-Exposure: prevention and recovery are interrelated to issues on land property rights and sense of safety; mitigation is interrelated to 'Topo' vulnerability and sense of comfort; and repetitive evacuation practices and costly preparedness are interrelated to sense of origin.

In interviews with residents of these study areas, we found that their houses have been in existence for about 70-100 years, with most coming to own these houses through inheritance; these locals were born and raised in these areas. There are some cases of in-migration to these 'hazardous' sites. This usually happens when the extended family moves in or near the homestead of either couple. The desires of these locals to live in proximity to their relatives and in-laws create a form of clustering of family relations which also influences the desire to live in an area. These are, however, mere circumstances that locals live to accept as a reality. Their love of place or sense of origin may have strong sentimental or familial values, but these are still influenced by other factors of Topophilia such as the sense of comfort.

Residents place a strong value to their place being close to basic and social services - which is how they qualify 'comfort'. As observed in the case of Guinobatan, the locals in the Poblacion (town center) value the easy and convenient access to the Rural Health Unit, the offices of the Local Government Unit, Banks, Groceries, the Public Market, and commercial and food establishments. Although they are beginning to experience stresses related to urban life, such as traffic and high population density, they are unwilling to relocate from their present sites, despite the history of natural disaster that befell the area. Take the case of Typhoon Reming: floods which were exacerbated by lahar flow from the volcano forced flood waters into the Poblacion residential site, with a maximum height of three meters. In Budiao, all the residents were forced to evacuate, losing most of their homes and livelihood to the lahar flow and typhoon winds. Residents in Guinobatan evacuated the area, only to return and rebuild, their attachment to their place is stronger than the logical need to permanently relocate to safer areas. In Budiao, some of its original inhabitants chose to return to the area due to the same attachments to their place, coupled with the lack of alternatives or access to offers of rehousing or relocation.

It is easy to assume that a sense of safety is difficult to have or obtain in a setting where settlements are located at the base of an active volcano. However, as we look deeper into the histories of these families, there are cases when the choice to settle in a specific area was driven by the need for a safer place. During the Spanish occupation of the Philippines, the system of concentrating populations in a specific area gave rise to the establishment of basic, social, and protective services. The original settlement was driven by the Spanish zoning policy, and the desire to live close to the Poblacion. However, with the advent of more sophisticated road networks and modes of transportation, it became easier to live in farther areas, closer to orchards and farms. The desire then, to move to the poblacion, changed as a matter of safety, when the presence of insurgents in rural areas. SOme families had to relocate due to fear of harassment; this was mostly during the 80 's.

\section{CONCLUSIONS}

Understanding the non-spatial and non-physical interactions within our geophysical space is a prerequisite to studying how these interactions play out in the real world. The challenge in replicating phenomena in a digital space, as we would in Geographic Information Systems, is that what is usually represented as a rectangular grid, polygons, and points, do not 
necessarily reflect the actual circumstances of the people moving within them. Fortunately, we have existing models hewn from Christaller's Central Place theory, that proposes the Hexagon as an appropriate representation of spheres of influence, while maintaining regularity in sectioning the geographic plane. In this paper we have demonstrated that a hexagonal lattice is a promising way of binning multiple information, providing a better image of natural and/or anthropogenic phenomena in digital space. This is perhaps most useful for information that form the basis of policy and governance; where multiple forms of information and visualization exist, without a cohesive method of integration. By binning information in a hexagonal lattice, as demonstrated in this paper, we integrate different types of data and information into a uniform system of representing exposure and topophilia data, to aid a better policy and decision making model.

There are many factors that come into policy and decision making, and most of these are determined or identified by considering variables such as geology, meteorology, development and land laws, and disaster risk reduction management principles. Despite being exposed to natural hazards, and despite the historical recurrences which had once led to the total destruction of entire towns, residents are willing to return to the original settlements to rebuild and remain. This is why we propose that the human sphere and its non-spatial variables be considered.

Undoubtedly, the factors of Topophilia complicate even the most logical and scientific options for disaster risk reduction and mitigation. This paper finally concludes that the topophiliaexposure concept model reflects the phenomena of disaster risk. Exposure complicated by the "love of land" will prevail, and may increase; surely this will cause complexities in Disaster Risk Reduction and Management, thus Topophilia is locational, political and socio-cultural in nature. It is therefore worthy to consider that the non-spatial and non-physical aspects of hazard and exposure are of relative importance with the spatial and physical factors often considered in policy and decision making.

\section{ACKNOWLEDGEMENTS}

We acknowledge: PhiLIDAR Program for the authorization to use the DTM, DSM, Orthophotos and Flood Hazard Maps $(5,25,100 \mathrm{Yr})$ for Region V; OpenStreetMap data licensed under the Open Database 1.0 License; NAMRIA, DENR-MGB, PHIVOLCS; Thanks to ESRI through Geodata Systems Technologies, Inc for the software trial ArcGIS Desktop student license; and other government agencies for the maps they published. We would like to thank Mr. Junniel Grutas for volunteering to conduct the interviews of the locals. and finally, we acknowledge the full support of the Research and Development Management Division, Office of the VP for RDE, Bicol University, Legazpi City for the support and funding the research entitled "Agent-Based Assessment of Naturalness of 'Topophilia-Exposure' (ABANTE)”.

\section{REFERENCES}

Abante, A.M. R., Abante, C. G. R., Unpublished research entitled "Agent-Based Assessment of Naturalness of 'TopophiliaExposure' (ABANTE)”. Bicol University. Legazpi City

Abante, A. M. R. (December 2018). Understanding Preparedness Insufficiency in the Context of DRRM: A Case Study in Malinao, Albay, Philippines. In Recent Advances in Geo-Environmental
Engineering, Geomechanics and Geotechnics, and Geohazards (pp. 497-501). Springer, Cham.

Abante, A. M. R., \& Abante, C. G. R. (February 2018). Sensitive Land Use Planning, Malinao, Albay, Philippines. In IOP Conference Series: Earth and Environmental Science (Vol. 123, No. 1, p. 012001). IOP Publishing.

BSP. (2019). List of Financial Service Access Points ATM ONLYs at BICOL REGION ALBAY GUINOBATAN. Retrieved July 30, 2019, from http://www.bsp.gov.ph/ifas/listoffis_dirsrch.asp

Cappellari, M., \& Copin, Y. (2003). Adaptive spatial binning of integral-field spectroscopic data using Voronoi tessellations. Monthly Notices of the Royal Astronomical Society, 342(2), 345354.

DepEd. (2019). List of Schools. Retrieved July 30, 2019, from https://ebeis.deped.gov.ph/beis/reports_info/masterlist

Fano, J. A., Alpasan, M. T., Mitsunaga, T., Tokunaga, Y. (2007) The Mayon 2006 Debris Flow: The Destructive Path of Typhoon Reming (Int'l Name: Durian). https://www.jica.go.jp/project/philippines/0600933/04/pdf/FCS EC_Technical_Report_3.pdf

Getis, Arthur \& Getis, Judith (1966) Christaller's Central Place Theory, Journal of Geography, 65:5, 220-226, DOI: $10.1080 / 00221346608982415$

Gold, C. (2016). Tessellations in GIS: Part I-putting it all together. Geo-spatial Information Science, 19(1), 9-25.

Janelle, D. G. (1968). Central place development in a time-space framework. The Professional Geographer, 20(1), 5-10.

Johnson, M. P., Burrows, M. T., Hartnoll, R. G., \& Hawkins, S. J. (1997). Spatial structure on moderately exposed rocky shores: patch scales and the interactions between limpets and algae. Marine Ecology Progress Series, 160, 209-215.

Lynch, K. (1990). The Image of the City. United States of America: Twentieth Printime.

Oat, C., Barczak, J., \& Shopf, J. (2008). Efficient spatial binning on the GPU. SIGGRAPH Asia.

Oksanen, J. (2013). Can binning be the key to understanding the uncertainty of DEMs?. In Proceedings of the GIS Research UK (GISRUK) 3.-5.4. 2013, Liverpool.

Owen, N. G. (1984). Prosperity Without Progress: Manila Hemp and Material Life in the Colonial Philippines. United States of America: University of California Press.

Paguican, E. M. R., Lagmay, A. M. F., Rodolfo, K. S., Rodolfo, R. S., Tengonciang, A. M. P., Lapus, M. R., ... \& Obille, E. C. (2009). Extreme rainfall-induced lahars and dike breaching, 30 November 2006, Mayon Volcano, Philippines. Bulletin of volcanology, 71(8), 845-857.

Philippines, Department of the Interior and Local Government, Bureau of Local Government Development. (2008). A Rationalized Planning System in the Philippines (1st ed., pp. 2325). Philippines: DILG. 
Philippines, NDRRMC. (2018). NDRRMC Update: SitRep No. 57 re Mayon Volcano Eruption (p. 57).

PSA. (2016, June 04). Population of Region V - Bicol (Based on the 2015 Census of Population). Retrieved from https://psa.gov.ph/content/population-region-v-bicol-based2015-census-population

Sui, D., Elwood, S., \& Goodchild, M. (Eds.). (2012). Crowdsourcing geographic knowledge: volunteered geographic information (VGI) in theory and practice. Springer Science \& Business Media.

Usamah, M., \& Haynes, K. (2012). An examination of the resettlement program at Mayon Volcano: what can we learn for sustainable volcanic risk reduction?. Bulletin of volcanology, 74(4), 839-859.

Zamir, R., Shamai, S., \& Erez, U. (2002). Nested linear/lattice codes for structured multiterminal binning. IEEE Transactions on Information Theory, 48(6), 1250-1276. 